DOI: https://doi.org/10.31933/dijdbm.v3i1

Received: 10 November 2021, Revised: 19 December 2021, Publish: 20 January 2022

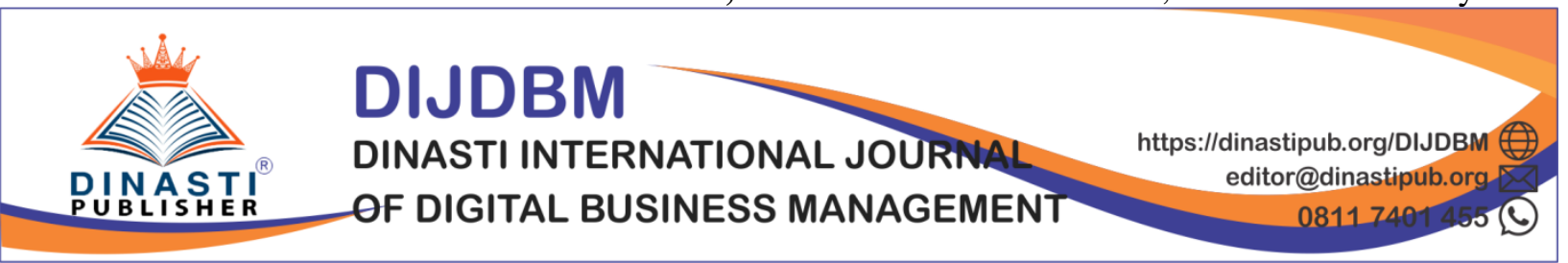

\title{
DETERMINATION OF PURCHASE DECISIONS AND CUSTOMER SATISFACTION: ANALYSIS OF BRAND IMAGE AND SERVICE QUALITY (REVIEW LITERATURE OF MARKETING MANAGEMENT)
}

\author{
Hapzi Ali $^{1}$, Veithzal Rivai Zainal ${ }^{2}$, Ridho Rafqi Ilhamalimy ${ }^{3}$ \\ ${ }^{1}$ Senior Lecturer, Universitas Bhayangkara Jakarta Raya (UBHARA), hapzi@ dsn.ubharajaya.ac.id \\ ${ }^{2}$ Senior Lecturer, Universitas Mercu Buana (UMB), Jakarta, veithzal47@ gmail.com \\ ${ }^{3}$ Student of Magister Management, Universitas Mercu Buana Jakarta. rafqiridho@gmail.com
}

\begin{abstract}
The purpose of writing Literature Review Papers is to determine the effect of service quality and brand image variables on purchasing decisions and customer satisfaction. With qualitative methods and Library Research. The purpose of writing this article is to build a hypothesis of the influence between variables to be used in further research. The results show that service quality affects purchasing decisions, service quality affects consumer satisfaction, brand image affects purchasing decisions, brand image affects consumer satisfaction and purchasing decisions affects consumer satisfaction.
\end{abstract}

Keywords: Brand Image, Service Quality, Purchase Decisions, Customer Satisfaction.

\section{INTRODUCTION}

Every student, both Strata 1, Strata 2 and Strata 3, is required to conduct research in the form of theses, theses and dissertations. Likewise for lecturers, researchers and other functional staff who actively conduct research and make scientific articles for publication in scientific journals.

Based on the empirical experience of many young students and lecturers as well as other researchers, it is difficult to find supporting articles in research as previous research or as relevant research. Articles as relevant researchers are needed to strengthen the theory being studied, to see the relationship between variables and build hypotheses, it is also very necessary in the discussion section of research results.

This article discusses the influence of brand image and price on trust and their impact on purchasing decisions, (A Study of Marketing Management Literature). Of course, not all factors that influence purchasing decisions and customer satisfaction in this article, this is only a small part that will be reviewed and reviewed.

Formulation of the problem. 
Based on the background, it can be formulated the problems to be discussed in order to build hypotheses for further research, namely:

1. Does brand image affect purchasing decisions?

2. Does brand image affect customer satisfaction?

3. Does service quality affect purchasing decisions?

4. Does service quality affect customer satisfaction?

5. Does purchasing decisions affect customer satisfaction?

\section{THEORITICAL REVIEW}

\section{Customer Satisfaction}

According to Kotler and Armstrong (2013: 16) customer satisfaction is the level where the perceived performance of the product is in accordance with buyer expectations. If the product's performance is deemed not meeting customer expectations, then the customer will be disappointed and vice versa. If the product's performance is considered in accordance with customer expectations, then the customer will be satisfied. According to Sofjan Assauri (2012: 176), customer satisfaction is a measure of the success of a marketing strategy in marketing products. Measuring the level of customer satisfaction is a difficult job and requires certain criteria. Based on the definition of customer satisfaction, it can be interpreted that customer satisfaction is the level where the perceived performance of the product is in accordance with buyer expectations. Increased customer satisfaction has the potential for long-term and short-term growth that has an impact on repeat purchases.

According to Hamdani et al., (2011: 80), customer satisfaction is the level of feeling where a person states the results of a comparison of the performance of a product / service received and expected. Customer satisfaction and dissatisfaction with a product as the end of a sales process has its own impact on behavior customers to these products.

There are a number of methods for measuring customer satisfaction described by Kotler and Keller (2012: 140), namely:

a. Periodic survey. It can track customer satisfaction directly and also ask additional questions to measure repurchase intention and the likelihood or willingness of respondents to recommend a company and brand to others.

b. Customer loss rate. Companies can observe customer loss rates and contact customers who have stopped buying or switched to another supplier to find out why.

c. Mysterious shopper. Companies can employ mysterious shoppers to act as potential buyers and report the strong and weak points they experience in buying the company's products and competitors' products. Managers themselves can enter into the sales situation of companies and competitors where they are not recognized and experienced the treatment they are receiving, or they can call their own company and ask questions and complaints to see how the employee handled the call.

The following are indicators of customer satisfaction that have been developed (Bhinawan \& Ali, 2017): 1) Expectation; 2) Experience; 3) Overall satisfaction; 4) Recommend other products; 5) Shows immunity to offers from competitors.

Customer satisfaction has been researched by many previous researchers, including by (Kristomi et al., 2016), (M \& Ali, 2017), (Kusuma et al., 2014), (Brata et al., 2017), (Limakrisna \& 
Ali, 2016), (Hoe, 2018), (Ishaq et al., 2014), (Sumatera et al., 2019), (Ali, 2019), (Perdana et al., 2018), (Cao et al., 2018), (Diawan et al., 2016), (Amelia et al., 2015)

\section{Purchase decision}

Purchasing decision, is the selection of two or more alternative purchasing decision choices, which means that someone can make a decision, there must be several alternative choices. The decision to buy can lead to how the decision-making process is carried out (Schiffman and Kanuk, 2009: 30). This is in line with (Sumarwan, 2011: 357) explaining that a purchase decision is a decision as the selection of an action from two or more alternative choices. Another case with (Kotler, 2012: 166) explaining the purchase decision is a purchase decision process consisting of five stages carried out by a consumer before arriving at a purchase decision and then postpurchase. Consumer behavior will look at the behavior of each individual, household or organization about how they process before making a purchase decision, as well as their actions after obtaining and consuming products, services or ideas. Based on the description above, it can be summarized that consumer decision making is a process that collects and combines information and knowledge to evaluate two or more alternative behaviors and choose one of them which can be seen from each individual or organization how the process is before making a purchase.

\section{Purchasing Decision Process}

According to Kotler and Armstrong (2012: 176) consumers will go through 5 (five) stages of the purchase decision process. These stages can be seen in the Figure below.

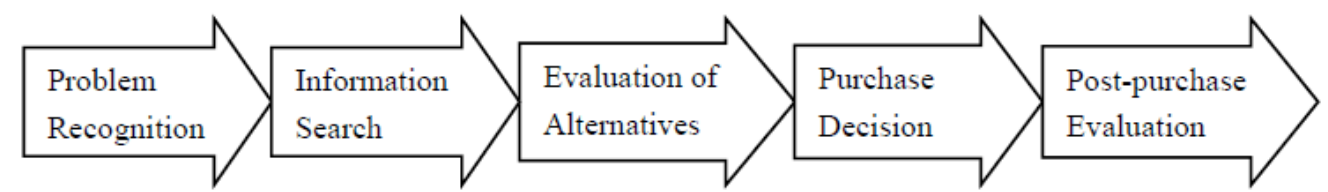

Figure 1. Model Decision Making Process

Source: Kotler dan Armstrong (2012:176)

Based on the decision-making process model above, the following is an explanation of the five stages (Kotler and Armstrong, 2012: 176), namely:

1) Problem Recognition

The buying process starts when the buyer recognizes a problem or need. The recognition of this need is intended to identify unmet and unfulfilled needs and wants.

2) Information Search

An already interested consumer might be looking for more information but maybe not. Consumers can get information from several sources, including:

a) Personal Resources: Family, friends, neighbors.

b) Commercial sources: Advertisements, salespeople, agents, packaging, displays.

c) Public Sources: Mass media, consumer assessment organizations.

d) Source of Experience: Handling, inspection, use of the product.

3) Evaluation of Alternatives

The stage of the buyer's decision, which is when consumers use the information to evaluate alternative brands in the choice of device. This evaluation cannot be separated from the influence of the resources at hand (time, money, information) or the risk of wrong selection.

4) Purchase Decision 
In the evaluation stage, consumers form preferences for brands that are in the choice set. Consumers can also form an intention to buy, because of loyalty to the chosen brand.

5) Post Purchase Behavior

The stage of the purchase decision process, which is when consumers take further action after purchasing based on satisfaction.

Indicators of purchasing decisions from previous research such as(Yunita \& Ali, 2017) use five indicators, namely:1) Product introduction; 2) Search Information; 3) Alternative evaluation; 4) Purchase Decision; 5) Post-Purchase Behavior.

Purchasing decisions have been researched by many previous researchers, including by (Yu et al., 2013), (Ali, 2019a), (Rosyid et al., 2013), (Kazmi \& Mehmood, 2016), (Sivaram et al., 2019), (Chovanová et al., 2015) (Durrani et al., 2015) (Foster, 2017). (Suhaily, 2017) (Dudu \& Agwu, 2014), (Anggita \& Ali, 2017), (Novansa \& Ali, 2017), (Brata et al., 2017), (Djatmiko \& Pradana, 2016), (Gan \& Wang, 2017), (Yunita \& Ali, 2017), (Rosyid et al., 2013) (Rödiger et al., 2016), (Amanah et al., 2017),(Konuk, 2018), (Ferdinand, 2014)(Larasetiati \& Ali, 2019), (Firmansyah \& Ali, 2019), (Zhao et al., 2019), (Jeaheng et al., 2020), (Damghanian et al., 2016), (Al-ekam, 2016), (Yen, 2019).

\section{Brand Image}

Brand image is a relatively consistent perception in the long term, so it is not easy to form an image, and once an image is formed it will be difficult to change it. The image formed must be clear and have a brand advantage compared to other brands. The formation of brand image is also influenced by consumer experience. Brand is basically an important thing in marketing a product. Manufacturers must be able to produce a brand that is easily recognizable, so that it can always be remembered by consumers with a good image, which then appears a brand image (Simamora, 2011: 33). According to (Kotler and Keller, 2016) Brand image is the consumer's perception of a brand as a reflection of the associations that exist in the minds of consumers. Brand image is an association that appears in the minds of consumers when remembering a particular brand. The association can simply appear in the form of certain thoughts and images associated with a brand. The image of the brand is related to attitudes in the form of beliefs and preferences for a brand. Consumers who have a positive image of a brand, will be more likely to make a purchase (Setiadi, 2003: 180). Thus the conclusion of the brand image is the consumer's perception of a brand that can always be remembered by consumers, where the good or bad image built by the brand will be able to influence consumer behavior in making purchases.

Quality is everything that is able to meet consumer wants or needs (Garpersz, 2011: 04). Meanwhile, products (Saladin, 2012: 142) are everything that can be offered to a market to be noticed, owned, used, and consumed so that they can satisfy wants and needs. According to Kotler and Armstrong (2014: 11), product quality is the ability of a product to demonstrate its function, this includes overall durability, reliability, accuracy, ease of operation, and product repair, as well as other product attributes. Mowen (2012: 61) states that product quality is an overall evaluation process to customers for improving the performance of a product. As for Kotler and Keller (2016: 164), product quality is the ability of an item to provide results or performance that is appropriate and even exceeds what the customer wants.

Research by (Kim et al., 2019) uses four indicators in measuring brand image, including: 1) prestige; 2) achieve high standards; 3) good service provision; 4) nice design.

Research on Brand Image has been widely studied by previous studies such as research developed by (M \& Ali, 2017), (Ali, 2019a), (Setyadi \& Ali, 2017), (Agussalim \& Ali, 2017), 
(Cheong \& Jang, 2008), (Kazmi \& Mehmood, 2016), (Yu et al., 2013), (Rosyid et al., 2013), (Sivaram et al., 2019), (Chovanová et al., 2015), (Durrani et al., 2015), (Foster, 2017), (Suhaily, 2017)

\section{Service Quality}

Tjiptono in Sunyoto (2012) states that quality or quality in the service industry is a presentation of a product or service according to the prevailing size at the place where the product is made and its delivery is at least the same as what consumers want and expect. According to Kotler (2008) service is any action or activity that a party can offer to another party, which is basically intangible and does not result in any ownership. According to Moenir (2008) service is a series of activities that take place regularly and continuously covering all the lives of people in society. This shows that service is related to inner satisfaction from

service recipient

Research by (Agussalim \& Ali, 2017)uses five indicators in measuring Service Quality, including: 1) Responsiveness; 2) Reliability; 3) Empathy; 4) Assurance and 5) Tangibles

Research on Service Quality has been widely studied by previous research such as research developed by (Anggita \& Ali, 2017), (Sivaram et al., 2019), (Yunita \& Ali, 2017), (Ali, 2019), (Ali, Evi, et al., 2018), (Agussalim \& Ali, 2017), (Bhinawan \& Ali, 2017), (Thanh Nguyen et al., 2019), (Hadibrata et al., 2018), (Setyadi \& Ali, 2017)

Table 1: Relevant previous research

\begin{tabular}{|c|c|c|c|c|}
\hline No & Author (tahun) & Previous Research Results & $\begin{array}{l}\text { Equation with this } \\
\text { article }\end{array}$ & Difference with this article \\
\hline 1 & $\begin{array}{l}\text { (Yu et al., } \\
2013)\end{array}$ & $\begin{array}{l}\text { Brand image has a positive } \\
\text { and significant impact on } \\
\text { purchasing decisions }\end{array}$ & $\begin{array}{l}\text { Brand image affects } \\
\text { purchasing decisions }\end{array}$ & $\begin{array}{l}\text { Brand image affects } \\
\text { purchasing decisions and } \\
\text { customer satisfaction }\end{array}$ \\
\hline 2 & (Ali, 2019a) & $\begin{array}{l}\text { Brand image has a positive } \\
\text { and significant impact on } \\
\text { purchasing decisions }\end{array}$ & $\begin{array}{l}\text { Brand image affects } \\
\text { purchasing decisions }\end{array}$ & $\begin{array}{l}\text { Brand image affects } \\
\text { purchasing decisions and } \\
\text { customer satisfaction }\end{array}$ \\
\hline 3 & $\begin{array}{l}\text { (Rosyid et al., } \\
\text { 2013) }\end{array}$ & $\begin{array}{l}\text { Brand image has a positive } \\
\text { and significant impact on } \\
\text { purchasing decisions }\end{array}$ & $\begin{array}{l}\text { Brand image affects } \\
\text { purchasing decisions }\end{array}$ & $\begin{array}{l}\text { Brand image affects } \\
\text { purchasing decisions and } \\
\text { customer satisfaction }\end{array}$ \\
\hline 4 & $\begin{array}{l}\text { (Nawi et al., } \\
\text { 2019) }\end{array}$ & $\begin{array}{l}\text { Brand image has a positive } \\
\text { and significant impact on } \\
\text { customer satisfaction }\end{array}$ & $\begin{array}{l}\text { Brand image affects } \\
\text { customer satisfaction }\end{array}$ & $\begin{array}{l}\text { Brand image affects } \\
\text { purchasing decisions and } \\
\text { customer satisfaction }\end{array}$ \\
\hline 5 & $\begin{array}{l}\text { (Bhinawan \& } \\
\text { Ali, 2017) }\end{array}$ & $\begin{array}{l}\text { Brand image has a positive } \\
\text { and significant impact on } \\
\text { customer satisfaction }\end{array}$ & $\begin{array}{l}\text { Brand image affects } \\
\text { customer satisfaction }\end{array}$ & $\begin{array}{l}\text { Brand image affects } \\
\text { purchasing decisions and } \\
\text { customer satisfaction }\end{array}$ \\
\hline 6 & $\begin{array}{l}\text { (Ali, Hapzi; } \\
\text { Krisna, N, L, } \\
\text { et al., 2016). }\end{array}$ & $\begin{array}{l}\text { Brand image has a positive } \\
\text { and significant impact on } \\
\text { customer satisfaction }\end{array}$ & $\begin{array}{l}\text { Brand image affects } \\
\text { customer satisfaction }\end{array}$ & $\begin{array}{l}\text { Brand image affects } \\
\text { purchasing decisions and } \\
\text { customer satisfaction }\end{array}$ \\
\hline 7 & $\begin{array}{l}\text { (Anggita \& Ali, } \\
\text { 2017) }\end{array}$ & $\begin{array}{l}\text { Service quality has a positive } \\
\text { and significant impact on } \\
\text { purchasing decisions }\end{array}$ & $\begin{array}{l}\text { Brand image affects } \\
\text { customer satisfaction }\end{array}$ & $\begin{array}{l}\text { Service quality affects } \\
\text { purchasing decisions and } \\
\text { customer satisfaction }\end{array}$ \\
\hline 8 & $\begin{array}{l}\text { be (Yunita \& Ali, } \\
\text { 2017) }\end{array}$ & $\begin{array}{l}\text { Service quality has a positive } \\
\text { and significant impact on } \\
\text { purchasing decisions }\end{array}$ & $\begin{array}{l}\text { Brand image affects } \\
\text { customer satisfaction }\end{array}$ & $\begin{array}{l}\text { Service quality affects } \\
\text { purchasing decisions and } \\
\text { customer satisfaction }\end{array}$ \\
\hline 9 & (Ali, 2019) & $\begin{array}{l}\text { Service quality has a positive } \\
\text { and significant impact on }\end{array}$ & $\begin{array}{l}\text { Service quality } \\
\text { affects purchasing }\end{array}$ & $\begin{array}{l}\text { Service quality affects } \\
\text { purchasing decisions and }\end{array}$ \\
\hline
\end{tabular}




\begin{tabular}{|c|l|l|l|l|}
\hline & & purchasing decisions & decisions & customer satisfaction \\
\hline 10 & $\begin{array}{l}\text { (Limakrisna \& } \\
\text { Ali, 2016) }\end{array}$ & $\begin{array}{l}\text { Service quality has a positive } \\
\text { and significant impact on } \\
\text { customer satisfaction }\end{array}$ & $\begin{array}{l}\text { Service quality } \\
\text { affects customer } \\
\text { satisfaction }\end{array}$ & $\begin{array}{l}\text { Service quality affects } \\
\text { purchasing decisions and } \\
\text { customer satisfaction }\end{array}$ \\
\hline 11 & (Ali, 2019). & $\begin{array}{l}\text { Service quality has a positive } \\
\text { and significant impact on } \\
\text { customer satisfaction }\end{array}$ & $\begin{array}{l}\text { Service quality } \\
\text { affects customer } \\
\text { satisfaction }\end{array}$ & $\begin{array}{l}\text { Service quality affects } \\
\text { purchasing decisions and } \\
\text { customer satisfaction }\end{array}$ \\
\hline 12 & $\begin{array}{l}\text { (Diawan et al., } \\
\text { 2016) }\end{array}$ & $\begin{array}{l}\text { Service quality has a positive } \\
\text { and significant impact on } \\
\text { customer satisfaction }\end{array}$ & $\begin{array}{l}\text { Service quality } \\
\text { affects customer } \\
\text { satisfaction }\end{array}$ & $\begin{array}{l}\text { Service quality affects } \\
\text { purchasing decisions and } \\
\text { customer satisfaction }\end{array}$ \\
\hline
\end{tabular}

\section{WRITING METHOD}

The method of writing scientific articles is by using qualitative methods and literature review (Library Research). Assessing theory and the relationship or influence between variables from books and journals both offline in the library and online sourced from Mendeley, Scholar Google and other online media.

In qualitative research, literature review must be used consistently with methodological assumptions. This means that it must be used inductively so that it does not direct the questions posed by the researcher. One of the main reasons for conducting qualitative research is that the research is exploratory (Ali \& Limakrisna, 2013).

\section{DISCUSSION}

\section{Effect of brand image on purchasing}

(Yu et al., 2013) If the company can form a strong brand image then consumers will not hesitate to make purchases at the company.(Ali, 2019a) Brand image can be formed by maintaining the quality of information that is easy for consumers to understand and by maintaining the quality of the products being sold.

According to (Kim et al., 2019) High brand image can be established with prestige, achieve high standards, good service delivery, good design.

(Yu et al., 2013) found that brand image has a positive impact on purchasing decisions. Brand image, brand awareness and price factors can positively influence the buying behavior of a product (Ali, 2019a). (Rosyid et al., 2013) Brand image has a positive effect on purchasing decisions. Brand image for purchasing electronic products is positively correlated and has a significant effect on buying interest (Kazmi \& Mehmood, 2016).

Increasing the positive image of the brand will have an impact on purchasing decisions (Sivaram et al., 2019). As well as (Chovanová et al., 2015) that brands have an impact on customer decision-making processes. As for (Durrani et al., 2015) brand image has a positive relationship with buying behavior. (Foster, 2017) Brand image has a positive influence on purchasing decisions.(Suhaily, 2017) brand image has a positive and significant effect on purchasing decisions.

\section{Effect of Brand Image on Customer}

(Bhinawan \& Ali, 2017) To improve the quality of service, it is necessary to record product reliability and improve company insurance, especially the promise of time for completion of work. This effort will increase customer satisfaction and customer loyalty. 
Brand image has a positive relationship with customer satisfaction where the brand is one of the powerful tools in marketing that can increase customer satisfaction (Nawi et al., 2019). as well as (Bhinawan \& Ali, 2017) Brand image has a positive and significant effect on customer satisfaction. The better the brand image of a company, it can increase customer satisfaction. As for (Fathollahi \& Aghaei, 2016) found that brand image has a positive and significant effect on customer satisfaction.

Then the quality of brand image has a positive and significant effect on customer satisfaction both partially and simultaneously (Ali, Hapzi; Krisna, N, L, et al., 2016). Research by (Mohammed \& Rashid, 2018) Brand image has a positive and significant effect on customer satisfaction. ( $\mathrm{Tu}$ et al., 2012) The company's brand image has a significant effect on customer satisfaction. And brand image has a positive effect on consumer satisfaction (Hamid et al., 2015)

\section{Effect of service quality on purchasing decisions}

(Anggita \& Ali, 2017) Consumers see the biggest point of the quality of service provided by employees is that employees are always open to receive complaints from customers, give personal attention to customers, employees are always open, and understand the specific needs of their customers.

To improve the quality of service that needs more attention is the aspect of assurance in the form of employees must have adequate knowledge to answer consumer questions. Guarantees given by employees to consumers for products sold in answering consumer questions and also employees consistently being polite to consumers (Yunita \& Ali, 2017)

Service quality variables have a significant influence on purchasing decisions, so all aspects of service quality need to be improved again. The aspect that needs more attention is the aspect of assurance that employees must have sufficient knowledge to answer consumer needs (Anggita \& Ali, 2017). service quality has a significant effect on purchasing decisions (Sivaram et al., 2019). Service quality has a significant positive effect on purchasing decisions.

This shows that the better the service, the more the purchasing decision will be (Yunita \& Ali, 2017) Factors forming service quality can affect customer satisfaction (Ali, 2019). And service quality has a positive and significant effect on purchasing decisions (Ali, Evi, et al., 2018).

\section{Effect of service quality on customer satisfaction}

(Agussalim \& Ali, 2017) If the company wants to maintain its competitive advantage in the market, the company must understand the aspects of service quality expected by consumers to differentiate the products sold by the company from competitors' products.

according to (Setyadi \& Ali, 2017) to improve service quality by forming expectations, subjective disconfirmation and good work results.

Service quality has a positive and significant effect on customer satisfaction. Good quality of service reflects all dimensions of the offering that results in benefits for customers. (Agussalim $\&$ Ali, 2017). Service quality has a positive and significant effect on customer satisfaction. The better the quality of service provided, it increases customer satisfaction. . (Bhinawan \& Ali, 2017). Service quality has a positive and significant effect on customer satisfaction (Thanh Nguyen et al., 2019).

There is an effect of service quality on customer satisfaction where reliability is the dominant factor to create positive empathy for service quality on customer satisfaction (Hadibrata et al., 2018). Service quality has a positive and significant effect on customer satisfaction with a positive contribution and has a strong correlation (Setyadi \& Ali, 2017). 


\section{Effect of Purchasing Decisions on Customer Satisfaction}

Customers generally feel one level of satisfaction, if the quality of services and products is in accordance with customer expectations, they will be satisfied, while they will feel disappointed because the quality of services and products is not in accordance with expectations (Limakrisna \& Ali, 2016). Purchasing decisions that lead to repeat purchases will create customer satisfaction (Ali, 2019).

(Yunita \& Ali, 2017) To shape purchasing decisions by improving Product recognition, Information Search, Alternative evaluation, Purchase Decisions, Post-Purchase Behavior.

As well as (Perdana et al., 2018) Purchasing decisions have a significant effect on customer satisfaction. Research by (Cao et al., 2018) Purchasing decisions have a positive and significant effect on customer satisfaction. As for (Diawan et al., 2016) The results showed that purchasing decisions had a positive and significant effect on customer satisfaction. (Amelia et al., 2015) Purchase decisions have a positive and significant effect on customer satisfaction.

\section{Conceptual Framework}

Based on the formulation of the problem of writing this article and a study of literature reviews from both relevant books and articles, the frame for this article is processed as below.

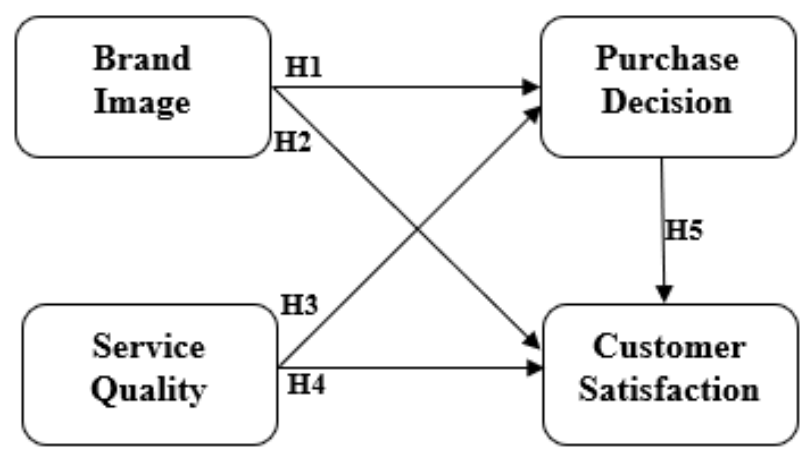

Figure 2: Conceptual Framework

Brand image and price have a relationship and influence trust and purchase decisions, either directly or indirectly.

Apart from the brand image and price variables that affect trust and purchase decisions, there are many other variables that influence it, including the variables:

1) Product quality: (M \& Ali, 2017), (Ali, Narulita, et al., 2018), (M \& Ali, 2017), (Ali, Evi, et al., 2018), (Prihartono \& Ali, 2020), (Riyanto et al., 2017), (Maisah \& Ali, 2020), (Brata et al., 2017), (Thanh Nguyen et al., 2019), (Ali, 2019), and (Anggita \& Ali, 2017).

2) Promotion: (Ali, Evi, et al., 2018), (Prihartono \& Ali, 2020), (Richardo et al., 2020), (Mappesona et al., 2020), (Sulistiorini \& Ali, 2017), (Hairiyah \& Ali, 2017), (Ali, Narulita, et al., 2018), and (Brata et al., 2017).

3) Price : (Brata et al., 2017), (Al-ekam, 2016), (Setiawan et al., 2020), (Amanah et al., 2017), (Yen, 2019), (Jeaheng et al., 2020), (Konuk, 2018), (Suhaily, 2017), (Susanty et al., 2016), (Dudu \& Agwu, 2014), (Anggita \& Ali, 2017), (Djatmiko \& Pradana, 2016), (Yunita \& Ali, 2017), (Rosyid et al., 2013). 


\section{CONCLUSIONS AND SUGGESTIONS}

\section{Conclusion}

Based on the theory, relevant articles and discussions, hypotheses can be formulated for further research:

1. Brand image effect on purchasing decisions.

2. Brand image affects customer satisfaction.

3. Quality of Service effect on purchasing decisions.

4. Service quality affects customer satisfaction.

5. Purchase decisions affect customer satisfaction

\section{Suggestion}

Based on the conclusions above, the suggestion in this article is that there are many other factors that influence purchasing decisions and customer satisfaction, apart from brand image and service quality at all types and levels of organizations or companies, therefore further studies are still needed. to find out what other factors can influence purchasing decisions and customer satisfaction other than those examined in this article.

\section{References}

Al-ekam, J. M. E. (2016). The mediating effect of brand trust on the influence of communication, price, and product quality on consumer purchase behaviour in a less-developed country. Malaysian Management Journal, 20(December), 87-97.

Ali, H. (2019a). Building Repurchase Intention and Purchase Decision: Brand Awareness and Brand Loyalty Analysis (Case Study Private Label Product in Alfamidi Tangerang). Saudi Journal of Humanities and Social Sciences, 04(09), 623-634. https://doi.org/10.36348/sjhss.2019.v04i09.009

Ali, H. (2019b). Purchase Decision and Repurchase Models: Product Quality and Process Analysis (Case Study of House Ownership Credit Financing in Permata Sharia Bank Jakarta). Scholars Bulletin. https://doi.org/10.36348/sb.2019.v05i09.006

Ali, H., Evi, N., \& Nurmahdi, A. (2018). The Influence of Service Quality , Brand Image and Promotion on Purchase Decision at MCU Eka Hospital. Business and Management Studies. https://doi.org/10.21276/sjbms.2018.3.1.12

Ali, H., \& Mappesona, H. (2016). Build brand image: Analysis Service Quality and Product Quality (case study at Giant Citra Raya). International Journal of Economic Research.

Ali, H., Narulita, E., \& Nurmahdi, A. (2018). Saudi Journal of Business and Management Studies ( SJBMS ) The Influence of Service Quality, Brand Image and Promotion on Purchase Decision at MCU Eka Hospital. Business and Management Studies. https://doi.org/10.21276/sjbms.2018.3.1.12

Amanah, D., Hurriyati, R., Gaffar, V., Wibowo, L. A., \& Harahap, D. A. (2017). Which is More Influential in Online Purchasing Decisions: Price or Trust? Which is More Influential in Online Purchasing Decisions: Price or Trust? November. https://doi.org/10.5220/0007090107980803 
Anggita, R., \& Ali, H. (2017). The Influence of Product Quality, Service Quality and Price to Purchase Decision of SGM Bunda Milk (Study on PT. Sarihusada Generasi Mahardika Region Jakarta, South Tangerang District). Scholars Bulletin. https://doi.org/10.21276/sb

Brata, B. H., Husani, S., \& Ali, H. (2017). The Importance of Quality Products, Price, Promotion, and Location to Product Purcese Decision on Nitchi At PT. Jaya Swarasa Agung in Central Jakarta. Saudi Journal of Business and Management Studies. https://doi.org/10.21276/sjbms

Cheong \&Jang. (2008). Determinants of Internet Usage in Ghanaian Hotels: The Case of the Greater Accra Region ( GAR ) Determinants of Internet Usage in Ghanaian Hotels : The Case of the Greater Accra Region ( GAR ). Journal of Hospitality \& Leisure Marketing, 15(3), 3741. https://doi.org/10.1300/J150v15n03

Chovanová, H. H., Korshunov, A. I., \& Babčanová, D. (2015). Impact of Brand on Consumer Behavior. Procedia Economics and Finance, 34(9), 615-621. https://doi.org/10.1016/s22125671(15)01676-7

Damghanian, H., Zarei, A., \& Siahsarani Kojuri, M. A. (2016). Impact of Perceived Security on Trust, Perceived Risk, and Acceptance of Online Banking in Iran. Journal of Internet Commerce, 15(3), 214-238. https://doi.org/10.1080/15332861.2016.1191052

Djatmiko, T., \& Pradana, R. (2016). Brand Image and Product Price; Its Impact for Samsung Smartphone Purchasing Decision. Procedia - Social and Behavioral Sciences, 219, 221-227. https://doi.org/10.1016/j.sbspro.2016.05.009

Dudu, O., \& Agwu, M. (2014). A Review of The Effect of Pricing Strategies on The Purchase of Consumer Goods. International Journal of Research in Management, Science \& Technology, 2(2), 88-102.

Ferdinand, T. dan. (2014). Analyzing the Influence of Price and Product Quality on Buying Decision. Jurnal EMBA, 2(3), 1255-1263.

Firmansyah, N., \& Ali, H. (2019). Consumer Trust Model: The Impact of Satisfaction and EService Quality toward Repurchase Intention in E-Commerce. 6256, 552-559. https://doi.org/10.21276/sjhss.2019.4.8.4

Foster, B. (2017). Impact of Brand Image on Purchasing Decision on Mineral Water Product "Amidis" (Case Study on Bintang Trading Company). American Research Journal of Humanities and Social Sciences, 2(1), 1-11. https://doi.org/10.21694/2378-7031.16023

Gan, C., \& Wang, W. (2017). The influence of perceived value on purchase intention in social commerce context. Internet Research, 27(4), 772-785. https://doi.org/10.1108/IntR-06-20160164

Hairiyah, S., \& Ali, H. (2017). Customer Decision Analysis in Taking Multipurpose Loan: Promotions, Locations and Credit Procedures ( A Case of the Bank " PQR Jakarta "). Saudi Journal of Business and Management Studies. https://doi.org/10.21276/sjbms.2017.2.3.6

Jeaheng, Y., Al-Ansi, A., \& Han, H. (2020). Impacts of Halal-friendly services, facilities, and food and Beverages on Muslim travelers' perceptions of service quality attributes, perceived price, satisfaction, trust, and loyalty. Journal of Hospitality Marketing and Management, 29(7), 787-811. https://doi.org/10.1080/19368623.2020.1715317

Kazmi, A., \& Mehmood, Q. S. (2016). The effect of electronic word of mouth communication and 
brand image on purchase intention: A case of consumer electronics in Haripur, Pakistan. Management Science Letters, 6, 409-508. https://doi.org/10.5267/j.msl.2016.5.003

Kim, E. J., Kim, S. H., \& Lee, Y. K. (2019). The effects of brand hearsay on brand trust and brand attitudes. Journal of Hospitality Marketing and Management, 28(7), 765-784. https://doi.org/10.1080/19368623.2019.1567431

Konuk, F. A. (2018). Price fairness, satisfaction, and trust as antecedents of purchase intentions towards organic food. Journal of Consumer Behaviour, 17(2), 141-148. https://doi.org/10.1002/cb.1697

Larasetiati, M., \& Ali, H. (2019). Model of Consumer Trust: Analysis of Perceived Usefulness and toward Repurchase Intention in Online Travel Agent. Journal of Economics and Finance, 3(8), 350-357. https://doi.org/10.21276/sjef.2019.3.8.5

Limakrisna, N., \& Ali, H. (2016). Model of Customer Satisfaction: Empirical Study At Fast Food Restaurants in Bandung. International Journal of Business and Commerce.

M, A., \& Ali, H. (2017). MODEL KEPUASAN PELANGGAN: ANALISIS KUALITAS PRODUK DAN KUALITAS LAYANAN TERHADAP CITRA MEREK PADA GIANT CITRA RAYA JAKARTA. Jurnal Manajemen. https://doi.org/10.24912/jm.v21i3.254

Maisah, \& Ali, H. (2020). Entrepreneurship culture development process: Implementation of Islamic education values in the Batik Jambi (case study in Seberang Jambi community). Talent Development and Excellence.

Mappesona, H., Ikhsani, K., \& Ali, H. (2020). Customer purchase decision model, supply chain management and customer satisfaction: Product quality and promotion analysis. International Journal of Supply Chain Management.

Mosunmola, A., Adegbuyi, O., Kehinde, O., Agboola, M., \& Olokundun, M. (2019). Percieved value dimensions on online shopping intention: The role of trust and culture. Academy of Strategic Management Journal, 18(1), 1-20.

Novansa, H., \& Ali, H. (1926). Purchase Decision Model: Analysis of Brand Image, Brand Awareness and Price (Case Study SMECO Indonesia SME products). Saudi Journal of Humanities and Social Sciences. https://doi.org/10.21276/sjhss

Pappas, I. O. (2018). User experience in personalized online shopping: a fuzzy-set analysis. European Journal of Marketing, 52(7-8), 1679-1703. https://doi.org/10.1108/EJM-10-20170707

Prihartono, \& Ali, H. (2020). The promises ethics and marketing concept strategy as a competitive advantage on private higher education (A survey on perception of product attributes and promotion mix in Indonesia). Talent Development and Excellence.

Richardo, Hussin, M., Bin Norman, M. H., \& Ali, H. (2020). A student loyalty model: Promotion, products, and registration decision analysis-Case study of griya english fun learning at the tutoring institute in wonosobo central Java. International Journal of Innovation, Creativity and Change.

Riyanto, S., Adila, L., \& Ali, H. (2017). The Effect of Incentives And Job Enthusiasm To Productivity of Go-Jek Driver At PT . Go-Jek Indonesia. Journal of Research in Business and Management. 
Rödiger, M., Plaßmann, S., \& Hamm, U. (2016). Organic consumers' price knowledge, willingness-to-pay and purchase decision. British Food Journal, 118(11), 2732-2743. https://doi.org/10.1108/BFJ-04-2016-0164

Rosyid, A. N., Djoko W, H., \& Widayanto. (2013). Pengaruh Kualitas Produk , Citra Merek , Harga dan Iklan Terhadap Keputusan Pembelian Sepeda Motor Honda Revo ( Studi Kasus pada Konsumen Sepeda Motor Honda Revo Astra Motor Kebumen ). Diponegoro Journal of Social and Politic, 1-8.

Setiawan, E. B., Wati, S., Wardana, A., \& Ikhsan, R. B. (2020). Building trust through customer satisfaction in the airline industry in Indonesia: Service quality and price fairness contribution. Management Science Letters, 10(5), 1095-1102. https://doi.org/10.5267/j.msl.2019.10.033

Setyadi, D. A. (2017). Build Customer Loyalty with CRM and Brand Image (Case Study on Giant Citra Raya). IOSR Journal of Business and Management, 19(01), 35-42. https://doi.org/10.9790/487x-1901043542

Sitio, T., \& Ali, H. (2019). Patient Satisfaction Model and Patient Loyalty: Analysis of Service Quality and Facility (Case Study at Rawamangun Special Surgery Hospital). Scholars Bulletin. https://doi.org/10.36348/sb.2019.v05i10.002

SiVARAM, M., Hudaya, A., \& Ali, H. (2019). Building a Purchase and Purchase Decision: Analysis of Brand Awareness and Brand Loyalty. Dinasti International Journal of Education Management And Social Science, 1(2), 235-248. https://doi.org/10.31933/DIJEMSS

Suhaily, L. (2017). EFFECT OF PRODUCT QUALITY, PERCEIVED PRICE AND BRAND IMAGE ON PURCHASE DECISION ( Study On Japanese Brand Electronic Product ). XXI(02), 179-194.

Sulistiorini, M. S., \& Ali, H. (2017). Customer satisfaction model: Product analysis, price, promotion and distribution (case study at PT Integrasia Utama). International Journal of Applied Business and Economic Research.

Suryana, S. (2010). Metodologi Penelitian. Universitas Pendidikan Indonesia, 58. https://doi.org/10.1007/s13398-014-0173-7.2

Susanty, A., Bakhtiar, A., \& Suliantoro, H. (2016). 6 atisfaction on 7 rust and / oyalty of , ndividual ) armers to ' airy \& ooperative Case 6 tudy ' airy 6 upply \& hain in Boyolali. 104108.

Thanh Nguyen, P., Ali, H., \& Agung Hudaya. (2019). MODEL BUYING DECISION AND REPEAT PURCHASE: PRODUCT QUALITY ANALYSIS (Case Study of Bank Permata Syariah Jakarta KPR Financing Customers). Dinasti International Journal of Management Science. https://doi.org/10.31933/dijms.v1i1.29

Yen, Y. S. (2019). Exploring the synergy effect of trust with other beliefs in television shopping. Management Decision, 58(3), 428-447. https://doi.org/10.1108/MD-11-2016-0814

Yu, C. C., Lin, P. J., \& Chen, C. S. (2013). How brand image, country of origin, and self-congruity influence internet users' purchase intention. Social Behavior and Personality, 41(4), 599-611. https://doi.org/10.2224/sbp.2013.41.4.599

Yunita, D., \& Ali, H. (2017). Model of Purchasing Decision ( Renting ) of Generator Set : Analysis of Product Quality, Price an Service at PT . Hartekprima Listrindo. Economics, Business and 
Management. https://doi.org/10.21276/sjebm.2017.4.11.12

Zhao, J. Di, Huang, J. S., \& Su, S. (2019). The effects of trust on consumers' continuous purchase intentions in $\mathrm{C} 2 \mathrm{C}$ social commerce: A trust transfer perspective. Journal of Retailing and Consumer Services, 50(January), 42-49. https://doi.org/10.1016/j.jretconser.2019.04.014 